\title{
COMMENT ON PETER HÄBERLE'S „WISSENSCHAFTLICHER RÜCKBLICK"
}

OLIVER LEPSIUS ${ }^{\dagger}$

\section{A Dossier in Honor of PETER HÄBERLE}

KEYWORDS: Civil Rights Theory; Structure of Institutions; Legal Interpretation.

Palavras-Chave: Teoria dos Direitos Civis; Estrutura das Instituições; Interpretação Jurídica.

$\uparrow$ Chair of Public Law at the University of Bayreuth, Germany. 


\section{TABLE OF CONTENT:}

I. INTRODUCTION .....................................................................94

II. CIVIL RIGHTS THEORY .............................................................94

III. THE STRUCTURE OF INSTITUTIONS .............................................99

IV. LAW, TEXT AND CONTEXT .....................................................102

V. TEXT AND BELIEF ................................................................107

VI. REFERENCES ...................................................................................110

\section{SUMÁRIO:}

I. INTRODUÇÃ O...................................................................................94

II. TEORIA DOS DIREITOS CIVIS ................................................94

III. A ESTRUTURA DAS INSTITUIÇÕES.................................................99

IV. DIREITO, TEXTO E CONTEXTO....................................................102

V. TEXTO E CRENÇA

VI. REFERÊNCIAS ............................................................................110 


\section{INTRODUCTION}

Peter Häberle's own report of his general ideas, his approach and his major academic publications gives, of course, an honest and comprehensive account of the major themes he addressed in his writings during the course of time. In general, Häberle's report is modest and refrains itself from assessing his writings or commenting on their reception in the academia around the world or in constitutional courts. The readers of this journal do not need an acclaim of Häberle's enormous achievements neither of his ingenious creativity. ${ }^{1}$ In my comment I cannot give an objective account or the praise and admiration he deserves. I am sure, the readers of this journal, well acquainted with Häberle's achievements and his stipend reputation, will not expect such a salute. May I refrain myself to some remarks from the view of a German professor of constitutional law, being incidentally Häberle's successor at the University of Bayreuth.

\section{Civil Rights TheORY}

In the 1960's Häberle entered the academic scene with an enormous success from the start on: His dissertation (Die Wesensgehaltsgarantie des Art. 19 Abs. 2 GG) was an instant success and his legendary lecture at the 1971 conference of the Vereinigung der Deutschen Staatsrechtslehrer on Grundrechte im Leistungsstaat ${ }^{2}$ (civil rights in the social state and in a protective dimension) became highly influential. The lecture established his wide esteem in the profession and made him famous at a young age,

\footnotetext{
${ }^{1}$ See, e.g., Robert CHRistian VAN OOYEn AND MARTin H. W. MÖllers, VerfassungsKultur: StaAt, Europa und PluRAlistische Gesellschaft bei Peter HäBerle (eds., 2016); Andreas Voßkuhle and Thomas Wischmeyer, Der Jurist im Kontext: Peter Häberle zum 80. Geburtstag, JAhrbuch Des ÖfFentLichen Rechts Der GegenWART, No. 63, 2015; Ingolf Pernice, Peter Häberle: der europäische Jurist, in ALEXANDER BlANKENAGEL ET. AL., VERFASSUNG IM DiSKURS DER WELT: LIBER AMICORUM FÜR PETER HÄBERLE ZUM SIEBZIGSTEN GEBURTSTAG (eds., 2004), p. 3 ss.; Wolfgang Graf Vitzthum, „Auf den Schultern von Riesen...", in PETER HÄBERLE, Kleine SCHRIFTEN: BeITRÄGE ZUR STAATSRECHTSLEHRE UND VERFASSUNGSKULTUR (ed. Wolfgang Graf Vitzthum, 2002); several tributes to Häberle in MARTIN MORLOK, DIE WELT DES VERFASSUNGSSTAATES: ERTRÄGE DES WISSENSCHAFTLICHEN KOLLOQUIUMS ZU EHREN VON PROF. DR. DR. H.C. MUlt. Peter HäBerle aUs ANLAß SEINES 65. GEbURTSTAGeS (ed., 2001).

2 VVDStRL 30 (1972), 43-131.
} 
being only 37 years old. One should not forget that in the 1950's and 1960 's civil rights was still a new subject and the German Federal Constitutional Court still a new institution without tradition in Germany. In other words, the whole area of civil rights jurisprudence was still a rather recent subject. What a great field of research for a young scholar!

When Häberle entered the scene major steps were already taken. The first academic commentaries of the civil rights' provisions of the German basic law interpreted them in an individualistic way: Civil rights are subjective rights. They protect the individual's freedoms against intrusions by the state. The Federal Court at Karlsruhe instantly took over this individualistic interpretation in procedural regard, too, opening the constitutional complaint broadly to individual recourses, and rooting the civil rights at the same time in the so-called objective value order of the basic law. ${ }^{3}$ The Elfes- and Lüth-decisions of $1957 / 58^{4}$ were the great starters of the court's forceful civil rights jurisprudence. Despite its rooting in a value-driven dimension, the court's civil rights-jurisprudence focused mainly on the so-called classical dimension of fundamental rights, namely the protection of individual freedoms in the status negatious (according to Georg Jellinek's classification). The Lüth case, however, also introduced an objective dimension. Yet, in the 1960's it was limited in two ways: On the one hand, the objective dimension remained a contributing factor for the primary goal of the protection of individual rights. Fundamental rights technically remained rights in the traditional sense of the status negativus notwithstanding the rhetoric of objective values the court used in Lüth. On the other hand, fundamental rights were not directed against the legislature but against the administration and, in the context of the 1950's and 1960's, primarily against the courts in Germany. One should remember that in the first twenty years of the Federal Republic neither the Bundestag nor the governments or the administration were the branches most likely to violate the constitution. In the political arena democracy prevailed. At that time, the Karlsruhe court did not act as a countermajoritarian power. Karlsruhe only rarely declared statues unconstitutional. It was different with the inferior courts, however. There, in the 1950's into the 1960's, many judges still were

\footnotetext{
${ }^{3}$ For recent accounts of the development, see MicHAELA HAILBRONNER, TRADITION AND TRANSFORMATIONS: THE RISE OF GERMAN CONSTITUTIONALISM (2015); JUSTIN COLLINGS, DEMOCRACY'S GUARDIANS: A HISTORY OF THE GERMAN FEDERAL CONSTITUTIONAL COURT, 1951-2000 (2015); MATTHIAS JESTAEDT, OlIVER LEPSIUS, CHRISTOPH MÖLLERS AND CHRISTOPH SCHÖNBERGER, DAS ENTGRENZTE GERICHT: EINE KRITISCHE BILANZ NACH SECHZIG JAHREN BUNDESVERFASSUNGSGERICHT (2011).

${ }^{4}$ BVerfGE 6, 32 - Elfes [1957]; 7, 198 - Lüth [1958].
} 
trained, educated and socialized in the "Third Reich". The personnel in the courts was rather to distrust whereas the personnel in the political branches were democratically accountable. Hence, the Federal Constitutional Court's civil rights jurisprudence in these times primarily engaged with constitutional complaints against judgements of inferior courts that disregarded or even violated the constitution. One should neither overlook that the Federal Constitutional Court itself was quarrelling over its superiority with other federal courts, the Bundesgerichtshof (High Court of Justice) in particular, who conceived itself as the true heir of the Reichsgericht and, hence, the guardian of the rule of law. The rivalry among the courts influenced the early civil rights jurisprudence because the Federal Constitutional Court could use the civil rights and the superiority of the constitution in order to surmount the Bundesgerichtshof claim and its evocation of natural law.

One needs to recall the historical context of the developing civil rights jurisprudence and the relationship among the German courts in order to understand Häberle's contribution to the civil rights jurisprudence. Häberle is the major proponent of extending the scope of fundamental rights to the legal order in general. He is backing and developing the objective strand: On the one hand, Häberle is complementing the classical civil rights theory with his famous status activus processualis (Grundrechtsschutz durch Organisation und Verfahren) arguing forcefully that fundamental rights require the development of procedural and organizational requirements in state action, and these devices furnish subjective rights. Otherwise, one would severely limit their scope in the area of social benefits and public service, i.e. in important areas of the law where the individual finds itself as a claimant and not as defender of his or her own liberty. Häberle's 1971 report at the Vereinigung opened the debate for these new dimensions of civil rights - an approach that has become vivid especially in the constitutions in Latin America. ${ }^{5}$ He may be credited for being one (if not the primary) inventor of a multidimensional approach to civil rights. Häberle, in a way, is introducing a procedural dimension into continental legal thinking that in common law countries is usually referred to as due process. On the other hand, Häberle is extending the binding force of fundamental rights

${ }^{5}$ See Roberto Gargarella, LATIN AMERICAN CONSTITUTIONALISM, 1810-2010 (2013);

Roberto Gargarella, Verfassungsgebung in Lateinamerika einst und jetzt: Themen und Thesen, JAHRBUCH DES ÖFFENTLICHEN RECHTS DES GEGENWART, No. 63, 2014; Fábio Corrêa Souza de Oliveira and Lenio Luiz Streck, The new Constitutions in latin America: is it necessary to reform constitutional theory, JAHRBUCH DES ÖFFENTLICHEN RECHTS DES GEGENWART, No. 63, 2014. 
against the legislature. Although the basic law in article $1 \mathrm{sec} .3$ submits all branches of government to the civil rights, until the late 1960's there was no practical need to intensify the meaning of civil rights with regard to the law-making power. Häberle's status activus procesualis required to do so. When parliament enacted a law granting social benefits or establishing social services and institutions (e.g. builds new universities and, by that means, opens access to higher education to a wider margin of the population), these laws must foresee procedural and organizational requirements for a fair distribution and access to those services according to the values encompassed by the fundamental rights.

Häberle's version of due process, his status activus processualis, does not address the judicature but both the legislature and the administration. That is a major achievement in the development of civil rights theory. However, it also stands at the beginning of a new political dimension of civil rights and the jurisprudence of the Federal Constitutional Court: The court began to scrutinize parliamentary acts, it invalidated legislation, it suddenly entered the arena of a counter-majoritarian power. In the context of the late 1960's and 1970's that endangered many reform acts by the new social-liberal coalition. Leftist reform statutes were under constitutional review. It was, of course, not Häberle's idea to check reform legislation. He rather intended to foster reform acts by outlining the procedural and organizational dimension of civil rights. However, with the extension of civil rights into the realm of objective requirements Häberle contributed to the intensified control of legislative action by the court. In his article, Häberle mentions the immediate success his approach found in the jurisprudence of Karlsruhe as well as its contributing role for the development of our extended understanding of civil rights as the fundament of the legal order in general. ${ }^{6}$ In hindsight, it may look a little bit paradoxical that Häberle, as an academic proclaiming reform and creativity, in the terms of politics contributed to an intensified judicial review of legislative action which limited parliamentary discretion. That was a judicial burden for Willy Brandt's social-liberal reform government, elected in 1969. It was only until this time that the Federal Constitutional Court struck down major parliamentary legislation, or, to put it differently, the court extended the binding force of the civil rights from the judiciary and the administrative branches to the legislature. The court, until so far credited for being a helping force or the new German democracy, working as democracy's

${ }^{6}$ See Peter Häberle, Ein wissenschaftlicher Rückblick, 2 JOURNAL OF INSTITUTIONAL

STUDIES 1 (2016), at para III.

2 JOURNAL OF INSTITUTIONAL STUDIES 1 (2016) 
governess, ${ }^{7}$ now became a counter-majoritarian power. The extended dimension of civil rights exercised political costs. One should bear that in mind. It does not curtail in any regard Häberle's contribution or creativity.

One may also assess Häberle's contribution to the development of the proportionality principle along these lines: Proportionality slowly developed in the case law of the 1950's and early 1960's; the famous Pharmacy-case of 1958 being a threshold. ${ }^{8}$ Proportionality originated in constitutional complaints against court decisions. Hence, one applied the proportionality tests to cases with a clear infringement of individual rights by state action in a clear factual situation. The precise factual setting of these constitutional complaints facilitated the applicability of the proportionality test: Both the right infringed by the means and the right promoted by the law were easily discernible. The factual setting of a precise case enabled the balancing process because the balancing could rely to a specific conflict of rights in a specific factual setting. Balancing need not become an abstract assessment of objective values rather it was always limited to a specific situation. The proportionality test, therefore, facilitated the trade-off of conflicting rights in certain situations. It did not provide general means for the ranking of values or the importance of rights. Proportionality was limited to legal problems located the status negativus. Häberle's approach in his dissertation tried to intensify the proportionality idea as a means to solve generalizable conflicts. He does not want to limit his approach to specific cases and, using the clause of the Wesensgehaltsgarantie of art. $19 \mathrm{sec} .2$ of the basic law rather wants to demonstrate the general dimension. In my view, again, Häberle is a proponent of the objectivization of civil rights. I think he generally accepts this position in his article when he is referring to his theme of the Grundrechtsstaat ${ }^{9}$, a legal system that is completely based on civil rights.

May I add a more general remark. One may note the general importance of civil rights theory in the German constitutional discourse. The German Staatsrechtslehre is positively biased towards civil rights, and the Federal Constitutional Court follows this direction and encourages it. It is astonishing to what an extent both German scholarship and the jurisprudence of Karlsruhe frame and treat constitutional issues within the context of fundamental rights even when more structural or jurisdictional issues are at stake. Just remember the Wesentlichkeitslehre,

7 See KARL LOEWENSTEIN, VerfaSSUNGSLEHRE (1959), p. 263.

8 BVerfGE 7, 377 - Apotheke [1958].

9 Peter Häberle, Ein wissenschaftlicher Rückblick, 2 JOURNAL OF INSTITUTIONAL STUDIES 1 (2016), at para III (n. 6).

2 JOURNAL OF INSTITUTIONAL STUDIES 1 (2016) 
i.e. the non-delegation question. It questions, what subject matters are of such an importance in order not to be delegated from parliament to other branches of government or to agency regulation? One would assume that such a jurisdictional question, a matter of relationship between the legislative branch and other branches, ought to be decided along structural arguments. The court, however, running out of structural arguments, takes refuge with the civil rights in deciding that at least those issues that trigger civil rights' concerns ought to be decided by parliamentary acts and may not be delegated to other branches. The academy acclaimed that approach. This example demonstrates both the reluctance of German constitutional scholarship and jurisprudence to a structural constitutional theory and the overwhelming trust in civil rights even when issues are at stake that do not refer to individual behavior. More than any other constitutional theory in the world, the German approach in general centers on fundamental rights and is rights-driven, enabling a value-based justification of constitutional law in general. This may be the primary legacy of the specific German constitutional theory and the judgments of the Federal Constitutional Court. Peter Häberle, perhaps together with Robert Alexy, is the prime intellectual who endorses and fosters this approach. In this regard he is a representative on a world scale and may rank, as a jurist, on the same reputational level as Niklas Luhmann and Jürgen Habermas, who are the representatives of (two rather different) philosophical approaches to civil rights issues in Germany.

\section{THE STRUCTURE OF INSTITUTIONS}

Häberle's early concentration on extended dimensions of civil rights and his exploitation of different forms of objective dimensions of civil rights had a major impact on his constitutional theory. He conceives fundamental rights as the primary constitutional force. When Häberle talks about institutions or about democracy as a principle, one always feels the sound of fundamental rights in his arguments. Häberle conceives the state in general as the sum of its branches and institutions, as a promoter of fundamental rights. Fundamental rights stand at the bottom of his understanding of institutions. He assesses and criticizes institutions mainly for their ability to foster fundamental rights. He ultimately roots democracy in human dignity. He also extends this rightsdriven understanding to the socially binding force of the constitution in what is perhaps his most famous article on the "open society of 
interpreters of the constitution". ${ }^{10}$ The constitution, he argues, and there he mainly thinks of fundamental rights, does not only address the branches of government. An effective force of the constitution requires that the constitution's acclaim becomes part of the societal discourse, part of everyday life. This, in turn, requires that the civil society as a whole is living according to the constitution and in doing so the civil society is acting as a genuine interpreter of the constitution. Constitutional interpretation is neither limited to the courts nor to academia nor to the political branches. It rather becomes a project for the civil society as a whole. Again, Häberle is extending the realm of the constitution. In particular, he extends his procedural understanding to the functioning of institutions and to the social life. His civil rights theory, at this point, turns into a political philosophy, and one may reward Häberle for being a social philosopher. Perhaps this still is a part of Häberle's oeuvre that needs to be discovered more closely.

The same may be true for his conception of legal pluralism. Häberle clearly endorses an open pluralistic society. Yet he grounds it not in individual behavior, in the pursuit of legitimate interests in a dispersed society, in group action or class struggle, he rather grounds pluralism in a societal trust in the constitutional values. These values in turn are grounded in the objective dimension of civil rights and also encompass procedural and organizational safeguards, equality of social chances and an open public discourse. Often pluralism theories take for granted that societies are dispersed by nature: people have different interests and therefore pursue different aims. For them, pluralism is a social fact. Häberle takes a different stand: In his view pluralism is a constitutional fact, a legal mandate.

If one takes a critical stand one must acknowledge that Häberle disregards several topics: First he does not deal with the political institutions themselves, their internal organization, their procedure, their jurisdiction, their relationships and conflicts to and with other institutions. Häberle's texts rather emphasize the general level above institutional differentiation, they emphasize fundamental values and constitutional cultures. They are not concerned with the institutional design in particular. Only one institution stands out: the constitutional

${ }^{10}$ Peter Häberle, Die offene Gesellschaft der Verfassungsinterpreten: Ein Beitrag zur pluralistischen und "prozessualen" Verfassungsinterpretation, 30 JURISTENZEITUNG 10 (1975). 
court. ${ }^{11}$ Häberle has not been interested, however, in the functioning of the political process as such, in the Bundestag or the Bundesrat or the governmental structure of the Länder.

Second he neglects the importance of interests and the conflicts arising out of these interests. I would say, Häberle does not like conflicts, not as a person privately and neither in a political system generally. One may see his endorsement of fundamental rights as a device to overcome conflicts and to establish a common understanding of the good values everybody should and actually does agree upon. There is some sort of paradox in his thinking at this point: On the one hand, he turns his interest to society and to the humane factor and, on the other hand, he fades out the actual amount of conflicts in a society and the institutional consequences the constitution draws from these conflicts. The constitutional design of institutions depends, of course, on the understanding and assessment of different interests and a functional solution how to articulate and promulgate these interests and how to transform them into the common good. Häberle's constitutional thinking does not start, as the Federal Papers did, with the conception of diverging interests but with the idea of a social and legal harmony grounded in fundamental laws. His revering of fundamental rights reflects his fear of conflict.

Third, one might say that he is generally an unpolitical thinker. ${ }^{12}$ To outline a legal world grounded in a system of fundamental rights that extend to general laws of institutional and societal behavior seems to be a rather idealistic understanding of how both, the law and the society, work. Häberle does not really take into account the political effects of his thinking. He rather is surprised or even offended if someone would accuse him of having taken a political stand. He would feel misunderstood. He may also lack the ability to acknowledge that other persons do have interests and may legitimately fight for their purposes, organize majorities and compromise in order to gain a majority.

Fourth one may regret a certain neglect of the individual person within his constitutional thinking. Häberle writes warmly and with obsession on individual freedoms and fundamental rights, he expounds human dignity and grounds the legal order in a rights-based conception.

${ }^{11}$ See, in particular, his selection of great articles on the German Federal Constitutional Court: PETER HÄBERLE, VERFASSUNGSGERICHTSBARKEIT - VERFASSUNGSPROZESSRECHT. AUSGEWÄHLTE BEITRÄGE AUS VIER JAHRZEHNTEN (2014).

12 Andreas Voßkuhle and Thomas Wischmeyer, Der Jurist im Kontext: Peter Häberle zum 80. Geburtstag, JAhrbuch Des ÖFFENTLichen Rechts Der GegenWART, No. 63, 2015, p. $425 \mathrm{~s} \mathrm{(n.} \mathrm{1)} \mathrm{also} \mathrm{discuss} \mathrm{this} \mathrm{aspect.}$

2 JOURNAL OF INSTITUTIONAL STUDIES 1 (2016) 
He nevertheless primarily understands rights from an objective point of view, not from a subjective or individualistic approach. This fits into what I called his unpolitical understanding of the legal order. To respect and accept the individual's goals, goals that are often rather irrational, requires a constitutional theory that outlines the purpose of the institutions or of the rights in order to cope with private interests. For instance, one should not forget that in our world civil rights are not refrained to humans. They are also generally extended to legal entities. A rights-based approach in our times is not a genuinely humane approach, it rather privileges private actors - and private actors are both natural and legal persons. An individualistic look at fundamental rights, hence, should take into account the legitimate private interests and the relevant social forces and powers that go along with these rights. Legal entities as major players in the civil society, however, are not in Häberle's focus, and neither are private interests in general. He rather is concerned with the common or public good.

Finally, it may be worth mentioning that administrative law almost completely escapes Häberle. He is a constitutional scholar in the strict sense - and this may be consequential because the study of administrative study would require what Häberle disregards: specific institutional settings, procedures and jurisdictions, individual interests, political underpinnings of the legal solutions, compromise-driven statutory law that comes out from changing political majorities. That would not be his world.

\section{LAW, TEXT AND CONTEXT}

Häberle's idealistic understanding of the constitution and its grounding in the objectivity of values, or, to put it differently, its embodiment of values, requires a specific methodological approach. As we all know, textual interpretation is a difficult task, even more so, when constitutional interpretation is at stake. Constitutional interpretation is more than a mere practical syllogism, where a constitutional provision is "applied" to statutory law of a lower hierarchy or to a set of facts. When we interpret the constitution, we also decide upon the value system, the inherent structure of the legal order, the societal effects of law, the scope of rights and to whom we attribute them, the participatory structure of government and the involvement of the people in the legitimacy of the law, and similar questions of general importance. Hence, constitutional interpretation is not only a legal process, it also is a political discussion 
with philosophical merits. It also is a public discourse.

How to cope with these dimensions of constitutional interpretation? One may rely on the interpretative outcome of institutions and their procedures: The text will be interpreted according to the specific factual situation by a specific institution and for a specific space of time. Interpretation, then, is depending on cases and jurisdictions: they constitute the interpretative context. That is not Häberle's approach considering his disregard of social facts, neglect of individual behavior or institutional jurisdictions. Häberle's interpretative context is shaped by his understanding of the text itself. Try to understand the text by abandoning the factual situations, by refraining from the plurality of actual conflicts. If everybody is in charge of the interpretation of the constitution, its meaning cannot depend on certain institutional settings or the decisions of cases. The meaning of a text comprises more than single case-related interpretations. Instead Häberle introduces his paradigm of textual steps and thresholds (Textstufenanalyse/Textstufenparadigma). ${ }^{13}$ The text discards its own relevance and it does so in different perceptions, so-called textual steps (Textstufen). A constitutional text is a lively document, recounted by its interpreters, amended by its interpretations. In Häberle's view there is no "final say" (kein "letztes Wort"), neither by the constitutional court nor by anyone else. The plurality of interpreters contributes to the continuous recounting of the constitution. They write forth the constitution. With this invention, Häberle manages to construe an interpretative context that is free from factual conditions. The text stands in the middle, the text is taken seriously. Häberle trusts in the reader's ability to grasp its content by interpreting previous interpretations, and by using the means of comparative law as well (comparisons as a legitimate form of legal interpretation). The reader is part of a community of interpreters and a range of interpretations.

The major advantage of his approach is that one can be more enthusiastic and more optimistic in interpreting texts as if one would limit the understanding of a text to its precedential application to certain sets of facts. One also can interpret the constitution in a more idealistic way and attribute more content to it than the jurisprudential outcomes would allow. Häberle is more optimistic than the courts or even than reality allow. In a way, he blends out the question of power and might. For the binding force of the constitution that is a major asset, because the constitution is seen as an aspiring goal, notwithstanding the actual

${ }^{13}$ See Peter Häberle, Ein wissenschaftlicher Rückblick, 2 JOURNAL OF INSTITUTIONAL STUDIES 1 (2016), at para X (n. 6).

2 JOURNAL OF INSTITUTIONAL STUDIES 1 (2016) 
situation. Häberle's approach is congenial to the normative claim of the constitution. He increases the constitution's normativity on an idealistic scale by taking it away from its actual restrictions in the judicial process.

One might inquire about the contexts of this endeavor: What could be the context of such a concept of interpretation? Häberle is in need of finding the setting for interpretation. If it is not primarily an undertaking of institutions, if it is not depending on specific factual situations, what could the context of textual interpretation be? Häberle's answer: Culture frames the context for the text's interpretation. Around 1980 Häberle introduced his idea of constitutional law as cultural study. He stresses his "cultural turn" in his paper as well. ${ }^{14}$ By interpreting the constitution, the author is part of a cultural endeavor. The constitution's relevance is a form of culture and hence its interpretation is embedded in culture. Culture, therefore, is not something the constitution aims at. One should not oppose culture and the constitution or assume one had to mediate between the two. In Häberle's view, the constitution is part of the culture. It ranks among other cultural emanations and expressions. As a text, it is treated like other important cultural texts who are also commonly interpreted and shape the collective consciousness and social behavior. As a piece of art, it is performed like literature or music. ${ }^{15}$ There again we find many interpreters building on previous interpretations and forming a collective interpretive community. By the advancement of the constitution to a cultural object Häberle manages to foster its binding force for the society as a whole. He opens an access to the constitution's understanding for the broader public. Constitutional interpretation becomes a cultural discourse, and this displays an access for everybody because every man is acquainted with culture, knows to understand culture and how to develop it. To present the constitution as culture also is a democratic project because it takes the constitution away from the predominance of lawyers and, at the same time, it is a value-based project, because it does not disdains the constitution into an every-day business. The constitution seen as culture shares the general esteem for culture, it benefits from it reverence. Legal texts, constitutions and their preambles in particular, benefit from an enhancement and advancement to cultural texts; they are upgraded in their interpretative meaning. In the following years, Häberle has convincingly demonstrated in what regard constitutions are treated like culture and work like culture. His books on

${ }^{14}$ See Peter Häberle, Ein wissenschaftlicher Rückblick, 2 JOURNAL OF INSTITUTIONAL STUDIES 1 (2016), at para VII (n. 6).

${ }^{15}$ See Peter Häberle, Ein wissenschaftlicher Rückblick, 2 JOURNAL OF INSTITUTIONAL STUDIES 1 (2016), at para VII (n. 6).

2 JOURNAL OF INSTITUTIONAL STUDIES 1 (2016) 
the cultural expression of constitutions (what he calls his tetralogy of national holidays, anthems, flags and memorials) furnish good examples, constitutional preambles being another illustrative device.

Häberle's cultural approach has two more effects: First it substitutes interdisciplinary research. Embedding the constitution in and as culture opens the interpretative understanding of the constitution to a public discourse and symbolism that does not require the specialized capacities of other disciplines. Culture functions as a common scientific ground where no discipline is privileged. Usually interdisciplinary studies are a very cumbersome and time-consuming endeavor. Häberle circumnavigates these burdens by harboring the constitution in culture. In the name of culture, one may use the interpretative devices of other disciplines without being limited to their disciplinary prerequisites. In that regard, "culture" is the symbol of both broadening the popular scope of the constitution and broadening the interpretative means besides the usual retrenchments of interdisciplinary efforts.

Second, Häberle may overcome national boundaries. Usually the interpretative communities are limited to the nation states. The cultural context, however, enables Häberle to surmount national limitations. In Europe, like in Latin America, the notion of a purely national culture is unconvincing. Culture provides a transmission belt for a legal interpretation that takes into account foreign influences and that respects the common ground of Western constitutionalism, which is true especially in Europe with its history of unification and harmonization in the European Community (now Union). Häberle presents his approach as a potentially European approach. At least he is able to furnish a discourse level where different legal cultures may equally participate and where they are inclined to interpret a legal text with a common aim in view. His book on European constitutional theory ${ }^{16}$ became an instant success and saw, until 2016, eight editions. There, Häberle transfers his cultural and value-oriented approach to the European level, emphasizing the common European values, understanding Europe as a community aiming at peace and solidarity. Häberle has boosted the traditional scope of an academic treatise. He has spelled out a mission, a legacy, he has written down his commitment to Europe. His common and cultural interpretation of constitutions and EU law constitutes a new European narrative. One might demur that his position is too idealistic. Some might even call it naïve. Yet in sum, it is a consistent development of his previous attitudes and candor, his deep belief in the compelling force of

16 Peter HÄBerle, EuropÄISCHE Verfassungslehre (7th ed., 2011); 8th ed. in preparation with Markus Kotzur.

2 JOURNAL OF INSTITUTIONAL STUDIES 1 (2016) 
texts in the inner self, his trust in the change of the world by texts and not by power. Häberle is a visionary - and in this regard, too, he stands out in the legal profession.

One may deplore that his thinking in the last twenty years has loosened the relation to the textual meaning while the cultural subtexts and meta-meanings increased. In the 1970s, Häberle still focused on German public law. German law got a value-based orientation. In the 1980s he gave up the treatment of black letter law and rather took law as an expression of cultural meanings and, finally, in the 1990s turned law into a cultural artifact. Häberle's development had gains and losses: $\mathrm{He}$ gained his reputation as a legal philosopher without exploring the traditional criteria of the philosophy of law. He is a legal ethicist who rather uses culture than philosophy for his aims. Culture delivers the bottom for the law's values, not, for instance, natural law. On the other hand, Häberle lost contact with the mainstream discourse in German public law. Most lawyers in his home country, obviously, missed the link to practical legal affairs and their every-day business. They partly admired, partly ignored Häberle's approach. Yet it did not help them with their individual conflicts at stake, with the concrete procedures before agencies or benches, with their struggling with textual gaps in positive law. The disconnection from the practical legal doctrine in Germany, however, helped to increase Häberle's international reputation and reception. He was easier to read and to adopt in foreign legal cultures exactly because his thinking and his approach were not closely connected to the particularities of the German legal system, neither to German legal texts nor to German legal institutions. Häberle's thinking became transferable. It could be transplanted to different legal worlds and at the same time claiming that all legal worlds belonged to one legal culture. This made it possible to integrate different legal cultures and systems. It gave them the impression of relevance for a word dimension of legal culture. It also enhanced the legal systems from smaller countries that are often neglected by comparative law. (Consider Häberle's affection for smaller countries, Switzerland as a constitutional laboratory in particular.) In Häberle's world, all constitutions, all legal systems are normatively equal just because he rejects the importance of power and might. This may explain Häberle's enormous success in countries with a younger constitutional tradition or with the need for a more value oriented foundation of their legal system (countries that need to overcome dictatorships, for instance), while other countries with a more institutional approach to law, an approach that builds on individualist behavior and conflict (the Anglo-American systems in particular), are more reluctant to read and venerate Häberle. 


\section{TEXT AND BELIEF}

One point remains to be addressed: In his article, Häberle mentions the subcutaneous influence of Luther and the protestant faith. Häberle, as we all know, is a proud Swabian. Swabia and particularly Württemberg, where Häberle's hometown of Göppingen is located, is a heartland of German Protestantism. The religious underpinnings of Häberle's theory become pretty clear if summed up like above, and Häberle himself openly refers to Protestantism several times looking back. Häberle's idealism, his trust in texts, his ability to fade out political realities, to ignore real interests and conflicts, they all may root in a deeply protestant belief. The centrality of texts in is thinking resembles the protestant veneration of the Bible as a text. The disregard of institutions and mandatory forms resembles the enhancement of every man to be able to read and to interpret the Bible and to recount its content to others and thereby promoting and proliferating faith. The plurality of interpretations resembles the idea of the presbytery of the believers, forming their own community of common readers without clear interior hierarchies. One might even see similarities between Häberle's theory of pluralism and a protestant conviction of the self-organization of the faithful. One should neither forget that Häberle's revered mentor, Konrad Hesse, was a staunch Protestant as well. ${ }^{17} \mathrm{It}$ is also worth noting that the most forceful objections to Häberle's thinking in Germany originate from thinkers who openly confess their belonging to Roman Catholicism, Ernst-Wolfgang Böckenförde and Josef Isensee being two prominent examples. At least it is understandable that from a catholic perspective the trust in texts and the neglect of formalism and of institutions that aggregate and formulate interests and solve conflicts, of institutions that exercise power and claim authority, is unconvincing.

The case-law of the Bundesverfassungsgericht sometimes reflects this alternative along religious lines. Perhaps the best example for a religious contingency in constitutional doctrine is the court's interpretation of the

17 See, e.g., Peter Häberle, Laudatio auf Konrad Hesse, in HANS-PETER SCHNEIDER AND RUDOLF STEINBERG, VERFASSUNGSRECHT ZWISCHEN WISSENSCHAFT UND RICHTERKUNST: FESTSCHRIFT FÜR KONRAD HESSE ZUM 70. GEBURTSTAGT (eds., 1990); Peter Häberle, In memoriam Konrad Hesse (1919-2005), 50 ZEITSCHRIFT FÜR EVANGELISCHES KIRCHENRECHT 4 (2005); Peter Häberle, Konrad Hesse (1919-2005), in Peter HÄBERLE, Michael KiLIAN AND HEINRICH AMADEUS WOLFF, STAATSRECHTSLEHRER DES 20. JAHRHUNDERTS (eds., 2015). 
principle of democracy and democratic legitimation. In the protestant version, represented by the court's famous Brokdorf-decision of 1985, democracy comprises a self-organization of the public discourse by the general public. The right to assemble and to demonstrate then is a necessary part of democracy and essential to a pluralistic society.$^{18}$ In the catholic version, represented by the famous doctrine of a legitimation chain (Legitimationsketten-Modell) ${ }^{19}$, democratic legitimacy is attributed by a chain of personal representatives and substantive acts that together ground in the people's will. In this alternative, Peter Häberle clearly stands on the first side, the pluralistic, non-hierarchical model of democratic self-organisation..$^{20}$ It may not wonder that Konrad Hesse took part in the Brokdorf court, ${ }^{21}$ whereas Ernst-Wolfgang Böckenförde was

${ }_{18}$ BVerfGE 69, 315 - Brokdorf [1985]. On the decision and its protestant underpinnings see Oliver Lepsius, Versammlungsrecht und gesellschaftliche Integration, in ANSELM DOERING-MANTEUFFEL, BERND GREINER AND OLIVER LEPSIUS, DER BROKDORF-BESCHLUSS DES BUNDESVERFASSUNGSGERICHTS 1985: EINE VERÖFFENTLICHUNG AUS DEM ARBEITSKREIS FÜR RECHTSWISSENSCHAFT UND ZEITGESCHICHTE AN DER AKADEMIE DER WISSENSCHAFTEN UND DER LITERATUR MAINZ (2015).

${ }^{19}$ BVerfGE 83, 37 (50-58) - Kommunales Ausländerwahlrecht Schleswig-Holstein [1990]; 83, 60 (71-75) - Ausländerwahlrecht Bezirksversammlungen Hamburg [1990]; 93, 37 (66-74) - Personalräte [1995]. For a critique of the legitimation chain-theory, see Bodo Pieroth, Plurale und unitarische Strukturen demokratischer Legitimation, 33 EUROPÄISCHE GRUNDERECHTE-ZEITSCHRIFT 12-16 (2006); Brun-Otto Bryde, Die bundesrepublikanische Volksdemokratie als Irrweg der Demokratietheorie, 5 STAATSWISSENSCHAFT UND STAATSPRAXIS 3 (1994); REDAKTION KRITISCHE JUSTIZ, DEMOKRATIE UND GRUNDGESETZ: EINE AUSEINANDERSETZUNG MIT DER VERFASSUNGSGERICHTLICHEN RECHTSPRECHUNG (ed., 2000). In the following years, the court eased the criteria and allowed open more open structures, see BVerfGE 107, 59 (86-101) - Wasserverband [2002]; 111, 191 (216 f.) - Notarkammer [2004]; 119, 331 (366367) - Arbeitsgemeinschaften nach dem SGB [2007].

${ }^{20}$ See Robert Christian van Ooyen, Der Brokdorf-Beschluss (1985) und die andere Demokratietheorie des Bundesverfassungsgerichts - Das Pluralismuskonzept des Ersten Senats (Kelsen und Popper/Hesse und Häberle) als Alternative zum legitimationsketten-Modell (Schmitt und Böckenförde), in ROBERT CHRISTIAN VAN OOYEN AND MARTIN H. W. MÖLLERS, VERFASSUNGS-KULTUR: STAAT, EUROPA UND PLURALISTISCHE GESELLSCHAFT BEI PETER HäBERLE (eds., 2016).

${ }^{21}$ See Oliver Lepsius and Anselm Doering-Manteuffel, Die Richterpersönlichkeiten und ihre protestantische Sozialisation, in DER BROKDORF-BESCHLUSS DES BUNDESVERFASSUNGSGERICHTS 1985: EINE VERÖFFENTLICHUNG AUS DEM ARBEITSKREIS 
the leading proponent of the chain-model..$^{22}$

Considering this, the more it is remarkable how successful Peter Häberle has been in catholic countries. Could there be a better proof of the integrating and pacifying potential of his constitutional ethic?

FÜR RECHTSWISSENSCHAFT UND ZEITGESCHICHTE AN DER AKADEMIE DER

WISSENSCHAFTEN UND DER LITERATUR MAINZ (2015).

22 Böckenförde had outlined this model in a lengthy article beforehand, see ErnstWolfgang Böckenförde, Demokratie als Verfassungsprinzip, in Josef Isensee and Paul Kirchhof, HANDBUCK DES STAATSRECHTS DER BUNDESREPUBLIK

DEUTSCHLAND - HDBSTR, Vol. I (eds., 1987), § 22, and one may speculate whether he was inclined to do so because of the Brokdorf-decisions vision of democracy that had come out two years earlier. 


\section{REFERENCES}

Andreas Voßkuhle and Thomas Wischmeyer, Der Jurist im Kontext: Peter Häberle zum 80. Geburtstag, JAHRBUCH Des ÖFFENTLICHEN ReCHTS DER GEGENWART, No. 63, 2015

Bodo Pieroth, Plurale und unitarische Strukturen demokratischer Legitimation, 33 EUROPÄISCHE GRUNDERECHTE-ZEITSCHRIFT 12-16 (2006).

Brun-Otto Bryde, Die bundesrepublikanische Volksdemokratie als Irrweg der Demokratietheorie, 5 STAATSWISSENSCHAFT UND STAATSPRAXIS 3 (1994)

Ernst-Wolfgang Böckenförde, Demokratie als Verfassungsprinzip, in Josef Isensee and Paul Kirchhof, HANDBUCK DES STAATSRECHTS DER BUNDESREPUBLIK DEUTSCHLAND - HDBSTR, Vol. I (eds., 1987).

Fábio Corrêa Souza de Oliveira and Lenio Luiz Streck, The new Constitutions in latin America: is it necessary to reform constitutional theory, JAHRBUCH DES ÖFFENTLICHEN RECHTS DES GEGENWART, No. 63, 2014.

Ingolf Pernice, Peter Häberle: der europäische Jurist, in ALEXANDER Blankenagel ET. AL., VERFASSUNG IM DisKURS DER Welt: Liber AMicorum FÜr PETER HÄBERLE ZUM SIEBZIGSTEN GEBURTSTAG (eds., 2004).

JuSTIN COLLINGS, DEMOCRACY's GUARDIANS: A HISTORY OF THE GERMAN FEDERAL CONSTITUTIONAL COURT, 1951-2000 (2015)

KARL LOEWENSTEIN, VERFASSUNGSLEHRE (1959).

Martin MorloK, Die Welt des VerfassungsstaAtes: ERTRÄGE DES WisSENSCHAFTLICHEN KOLLOQUIUMS ZU EHREN VON PROF. Dr. DR. H.C. MULt. Peter HäBerle Aus ANLAß SeINES 65. GebURTSTAGES (ed., 2001). 
Matthias Jestaedt, Oliver LePSIUS, CHRISTOPH MÖLLERS AND CHRISTOPH SCHÖNBERGER, DAS ENTGRENZTE GERICHT: EINE KRITISCHE BILANZ NACH SECHZIG JAHREN BUNDESVERFASSUNGSGERICHT (2011).

Michaela Hailbronner, TRAdition AND TRANSFORMATIONS: THE Rise OF GERMAN CONSTITUTIONALISM (2015).

Oliver Lepsius and Anselm Doering-Manteuffel, Die

Richterpersönlichkeiten und ihre protestantische Sozialisation, in DER BROKDORF-BESCHLUSS DES BUNDESVERFASSUNGSGERICHTS 1985: EINE VERÖFFENTLICHUNG AUS DEM ARBEITSKREIS FÜR RECHTSWISSENSCHAFT UND ZEITGESCHICHTE AN DER AKADEMIE DER WISSENSCHAFTEN UND DER LITERATUR MAINZ (2015).

Oliver Lepsius, Versammlungsrecht und gesellschaftliche Integration, in ANSELM DOERING-MANTEUFFel, BERND GREINER AND OLIVER LEPSIUS, DER BROKDORF-BESCHLUSS DES BUNDESVERFASSUNGSGERICHTS 1985: EINE VERÖFFENTLICHUNG AUS DEM ARBEITSKREIS FÜR RECHTSWISSENSCHAFT UND ZEITGESCHICHTE AN DER AKADEMIE DER WISSENSCHAFTEN UND DER LITERATUR MAINZ (2015).

Peter Häberle, Die offene Gesellschaft der Verfassungsinterpreten: Ein Beitrag zur pluralistischen und "prozessualen“ Verfassungsinterpretation, 30 JURISTENZEITUNG 10 (1975).

Peter Häberle, Ein wissenschaftlicher Rückblick, 2 JOURNAL OF INSTITUTIONAL STUDIES 1 (2016).

Peter HÄBERLE, EUROPÄISCHE VerFASSUnGSLEHRE (7th ed., 2011).

Peter Häberle, In memoriam Konrad Hesse (1919-2005), 50 ZEITSCHRIFT FÜR EVANGELISCHES KIRCHENRECHT 4 (2005). 
Peter Häberle, Konrad Hesse (1919-2005), in Peter HÄBerle, Michael Kilian AND HeInRICH AMAdeus WolfF, StaAtSRECHTSLEHRER Des 20. JAHRHUNDERTS (eds., 2015).

Peter Häberle, Laudatio auf Konrad Hesse, in HANS-PETER SCHNEIDER AND RUDOLF STEINBERG, VeRFASSUNGSRECHT ZWISCHEN WISSENSCHAFT UND RICHTERKUNST: FESTSCHRIFT FÜR KONRAD HESSE ZUM 70. GEBURTSTAGT (eds., 1990).

Peter HÄBERLE, VERFASSUNGSGERICHTSBARKEIT VERFASSUNGSPROZESSRECHT. AUSGEWÄHLTE BEITRÄGE AUS VIER JAHRZEHNTEN (2014).

REDAKTION KRITISCHE JUSTIZ, DEMOKRATIE UND GRUNDGESETZ: EINE AUSEINANDERSETZUNG MIT DER VERFASSUNGSGERICHTLICHEN RECHTSPRECHUNG (ed., 2000).

Robert Christian van Ooyen, Der Brokdorf-Beschluss (1985) und die andere Demokratietheorie des Bundesverfassungsgerichts - Das Pluralismuskonzept des Ersten Senats (Kelsen und Popper/Hesse und Häberle) als Alternative zum legitimationsketten-Modell (Schmitt und Böckenförde), in ROBERT CHRISTIAN VAN OOYen and Martin H. W. MÖLlers, Verfassungs-Kultur: StaAT, EuROPA Und PluRAlistische Gesellschaft bei Peter HÄBERLE (eds., 2016).

ROBERT CHRISTIAN VAN OOYEN AND MARTIN H. W. MÖLLERS, VERFASSUNGS-KULTUR: STAAT, EUROPA UND PLURALISTISCHE Gesellschaft bei Peter HäBerle (eds., 2016).

Roberto Gargarella, LATIN AMERICAN CONSTITUTIONALISM, 1810-2010 (2013). 
Roberto Gargarella, Verfassungsgebung in Lateinamerika einst und jetzt: Themen und Thesen, JAHRBUCH DES ÖFFENTLICHEN RECHTS DES GEGENWART, No. 63, 2014.

Wolfgang Graf Vitzthum, "Auf den Schultern von Riesen...", in PETER HÄBERLE, KLEINE SCHRIFTEN: BEITRÄGE ZUR STAATSRECHTSLEHRE UND VERFASSUNGSKULTUR (ed. Wolfgang Graf Vitzthum, 2002). 